\title{
PENGEMBANGAN PERANGKAT PEMBELAJARAN KIMIA MODEL KOOPERATIF DENGAN PENDEKATAN INKUIRI UNTUK MENINGKATKAN KETERAMPILAN BERPIKIR KRITIS SISWA SMA
}

\author{
Nurkhasanah $^{1)}$, Tukiran ${ }^{2)}$, Wahono Widodo ${ }^{3)}$ \\ ${ }^{1)}$ Mahasiswa Program Studi Pendidikan Dasar, Program Pascasarjana Universitas Negeri Surabaya \\ ${ }^{2), 3)}$ Dosen Pascasarjana Prodi Pendidikan Sains Univesrtitas Negeri Surabaya \\ E-mail:nur_khasanah16@yahoo.co.id
}

\begin{abstract}
This research is a research development of teaching materials a model cooperative with inquiry approach on chemistry learning sub-subject factors that affect the rate of reaction, including: syllabus, lesson plans, student worksheets, student's book and assessment sheet. This research was conducted at SMAN 5 Tuban through three stages: 1) Development of teaching materials with the model Thiagarajan, 2) Validation of teaching materials, and 3) Field try out with design One Group PretestPosttest Design. The results of this study are: 1) Teaching materials arranged by using cooperative learning model with inquiry approach are declared valid to be used in learning; a) the results of validation toward teaching materials that had been developed have good category and it can be used in teaching learning process; b) The level of difficulty for teahing materials developed are low and easy to be understood; c) Readability of instrument is high and the materials easy to understand by student; 2) The teaching materials is effective to be used in learning process, supported by: a) Learning outcome (product) is increase of high categories, b) student's critical thinking skills is increase of with high categories, c) students responded positively to the teaching materials developed, and 3) The teaching materials developed is practical to be used in learning process shown by; a) the lesson plan used is in good category; b) The student's activities are dominated by forms of inquiry activities, presentations, and group discussions. Based on the results of this research can be concluded that the teaching materials with cooperative learning model with inquiry approaches that have been developed fulfills the validity, effectiveness, and practical, feasible to implement to improving students' critical thinking skills.
\end{abstract}

\section{Keywords: Critical Thinking, Cooperative Model with Inquiry Approach}

Abstrak: Penelitian ini merupakan penelitian pengembangan perangkat pembelajaran model kooperatif dengan pendekatan inkuiri pada pembelajaran kimia SMA sub pokok bahasan faktor-faktor yang mempengaruhi laju reaksi, meliputi: silabus, RPP, LKS, Buku Ajar Siswa, dan Lembar Penilaian. Penelitian ini dilaksanakan di SMAN 5 Tuban melalui tiga tahap, yaitu 1) Pengembangan perangkat pembelajaran menggunakan model Thiagarajan, 2) Validasi perangkat pembelajaran, dan 3) Uji coba lapangan dengan rancangan "One Group Pretest-Posttest Design”. Hasil dari penelitian ini adalah: 1) Perangkat pembelajaran model kooperatif dengan pendekatan inkuiri dinyatakan valid untuk digunakan dalam pembelajaran model kooperatif dengan pendekatan inkuiri; a) hasil validasi perangkat pembelajaran yang dikembangkan berkategori baik dan dapat diterapkan dalam kegiatan belajar mengajar; b) Tingkat kesulitan perangkat pembelajaran yang dikembangkan rendah dan mudah dipahami siswa; dan c) Keterbacaan perangkat pembelajaran tinggi dan materi mudah dipahami oleh siswa; 2) perangkat pembelajaran dinyatakan efektif untuk digunakan dalam proses pembelajaran, yang didukung oleh; a) Tes hasil belajar produk meningkat dengan kategori tinggi, b) Keterampilan berpikir kritis siswa mengalami peningkatan dengan kategori tinggi, dan c) Siswa memberikan respon positif terhadap perangkat pembelajaran yang dikembangkan, dan 3) Perangkat pembelajaran yang dikembangkan bersifat praktis untuk digunakan dalam pembelajaran yang ditunjukkan dari; a) keterlaksanaan RPP dalam kategori baik; b) Aktivitas siswa didominasi bentuk-bentuk kegiatan inkuiri, presentasi, dan diskusi kelompok. Berdasarkan hasil penelitian dapat disimpulkan bahwa perangkat pembelajaran model kooperatif dengan pendekatan inkuiri yang telah dikembangkan memenuhi unsur kelayakan, keefektivan dan kepraktisan, sehingga layak diimplementasikan untuk meningkatkan keterampilan berpikir kritis siswa.

Kata kunci: Keterampilan Berpikir Kritis, Model Pembelajaran Kooperatif, Pendekatan Inkuiri

\section{PENDAHULUAN}

Era globalisasi ditandai dengan kemajuan dalam bidang ilmu pengetahuan dan teknologi. Penguasaan bidang teknologi dapat ditempuh melalui penguasaan sains yang lebih baik. Salah satu bagian dari sains adalah kimia, maka penguasaan kimia yang baik akan membawa andil yang berarti dalam menguasai bidang teknologi. Rotherdham dan Willingham (dalam Trisdiono, 2013) mencatat bahwa kesuksesan seorang siswa di masa depan bergantung pada penguasaan kecakapan abad 21. Kecakapan abad 21 yang dirumuskan oleh Partnership for 21st Century Skills meliputi kemampuan berpikir kritis, pemecahan masalah, komunikasi, dan kolaborasi. Kemampuan 
berpikir kritis dan berkolaborasi (bekerja sama dengan orang lain) merupakan bagian dari kemampuan yang harus dimiliki oleh seseorang untuk menghadapi tantangan di era globalisasi.

Pembelajaran ilmu pengetahuan dan teknologi di SMA adalah untuk memperoleh kompetensi lanjut ilmu pengetahuan dan teknologi serta membudayakan berpikir ilmiah secara kritis, kreatif, dan mandiri (Depdiknas, 2006). Berpikir kritis merupakan salah satu tujuan yang hendak dicapai dalam pembelajaran ilmu pengetahuan dan teknologi, sehingga berpikir kritis juga merupakan salah satu tujuan dalam pembelajaran kimia.

Di sisi lain, pendidikan sains di Indonesia menghadapi berbagai permasalahan. Berdasar hasil survei yang dilakukan oleh Trends in International Matematics and Science Study (TIMSS) (Martin, 2012) pada tahun 2011 yang dilakukan pada anak kelas VIII menghasilkan data bahwa kemampuan sains anak Indonesia menduduki peringkat 40 dari 42 negara. Rendahnya peringkat Indonesia menunjukkan pembelajaran sains selama ini belum mencapai apa yang ditargetkan oleh kurikulum, dan hasil kajian kurikulum yang dilakukan diduga kurikulum IPA di Indonesia belum diimplementasikan oleh kebanyakan sekolah (Depdiknas, 2007). Pembelajaran yang seharusnya menekankan pada proses inkuiri ilmiah dimungkinkan tidak terlaksana, karena masih berorientasi terhadap penguasaan teori dan hafalan, sehingga kemampuan belajar siswa menjadi terhambat.

Berdasarkan hasil Ulangan Akhir Semester (UAS) kimia kelas XI semester 1 Tahun Pelajaran 2012-2013 SMA N 5 TUBAN, nilai yang diperoleh anak-anak masih rendah yaitu siswa yang mencapai nilai KKM $(\mathrm{KKM}=75)$ di bawah $30 \%$. Padahal dari 40 soal yang diujikan, soal dengan kategori $\mathrm{C} 2=28 \%, \mathrm{C} 3=50 \%$, dan $\mathrm{C} 4=22 \%$. Beberapa ahli (Lai, 2011) berpendapat bahwa kemampuan analisis (C4), sintesis (C5), dan evaluasi (C6) pada Taksonomi Bloom merupakan sumber untuk mengajar dan menilai keterampilan berpikir tingkat tinggi (termasuk berpikir kritis). Data yang ada menunjukkan soal dengan kategori berpikir kritis hanya $22 \%$ yaitu 9 soal. Hal ini menunjukkan hasil belajar kimia dan keterampilan berpikir kritis siswa tersebut masih rendah.

Hasil studi pendahuluan terhadap RPP yang ada di SMAN 5 Tuban pada mata pelajaran IPA khususnya Kimia, menunjukkan bahwa model atau metode yang digunakan umumnya adalah pembelajaran langsung dengan metode ceramah, diskusi, pengamatan, tanya jawab, demonstrasi, dan penugasan. Berdasarkan pengalaman pribadi dan pengamatan pembelajaran yang dilakukan di kelas XI IPA, pada umumnya pembelajaran dilakukan dengan menggunakan metode ceramah diselingi dengan diskusi kelas dan tanya jawab, kemudian diakhiri dengan mengerjakan latihan soal. Pada saat guru menanyakan tentang suatu konsep, siswa cenderung menjawab pertanyaan sama dengan yang ada dalam buku, tetapi jika diminta memberi contoh-contoh di luar buku siswa tidak dapat menjawab. Hal ini menunjukkan siswa cenderung menghafal konsep-konsep seperti yang ada di buku tanpa memahami konsep tersebut.

Pada saat pembelajaran secara kelompok pelaksanaannya kurang efektif. Siswa sulit bekerja sama dengan kelompok dan cenderung individualis. Hal ini dibuktikan dengan didominasinya kegiatan kelompok oleh $1-2$ orang saja. Disisi lain, pada saat dilakukan presentasi kelas, diskusi kelas tidak berjalan dengan baik. Diskusi kelas hanya didominasi $3-4$ siswa dan yang lainnya hanya mendengarkan dan diam. Hal ini menunjukkan pembelajaran di SMAN 5 Tuban masih berpusat pada guru dan siswa cenderung menghafalkan konsep-konsep yang dipelajari, belum menunjukkan upaya yang terencana untuk memberdayakan keterampilan berpikir kritis. Selain itu siswa kurang dapat mengkomunikasikan konsep dan fakta-fakta, serta sulit bekerja sama dengan kelompok.

Saat ini telah diketahui berbagai model pembelajaran yang berpotensi memberdayakan kemampuan berpikir siswa. Beberapa model pembelajaran yang berpotensi memberdayakan kemampuan berpikir adalah authentic instruction, pembelajaran berbasis inkuiri, pembelajaran berbasis masalah, pembelajaran yang mendorong siswa memonitor dan mengarahkan pembelajaran sendiri (self regulated learning), cooperatif learning, dan project based learning (Corebima, 2010). Penelitian ini menggunakan model pembelajaran kooperatif yang dipadukan dengan pendekatan inkuiri, karena dengan menggunakan pendekatan inkuiri yang dipadukan dengan model kooperatif berpotensi memberdayakan keterampilan berpikir kritis. Ada hubungan antara berpikir kritis dengan pembelajaran kooperatif (Klimoviena, 2006). Pembelajaran dengan cara berkelompok dapat mengembangkan kemampuan berpikir kritis siswa disebabkan di dalam pembelajaran ini terjadi diskusi, klarifikasi ide, dan evaluasi ide orang lain (Gokhale,1995).

Berdasarkan kenyataan bahwa kemampuan berpikir kritis siswa SMAN 5 Tuban masih rendah dan pembelajaran inkuiri adalah pembelajaran yang baru maka penelitian ini menggunakan model kooperatif yang dipadukan dengan pembelajaran inkuiri untuk meningkatkan keterampilan berpikir kritis dan meningkatkan hasil belajar siswa. Penelitian ini menggunakan model kooperatif tipe STAD. Hal ini didasarkan pada pengamatan yang dilakukan pada saat pembelajaran secara kelompok siswa belum dapat 
bekerja dalam kelompok dengan baik. Menurut Slavin (2005) pembelajaran kooperatif tipe STAD adalah tipe pembelajaran kooperatif yang paling sederhana dan sesuai untuk yang baru menggunakan pembelajaran ini. Di samping itu dalam pembelajaran kooperatif tipe STAD diberikan kuis yang bertujuan untuk mengetahui kemajuan siswa dalam kerja kelompok serta dapat bekerja lebih giat dan memberikan kinerja lebih baik daripada sebelumnya. Pemberian penghargaan (reward) pada akhir pembelajaran memungkinkan setiap anggota kelompok lebih termotivasi dalam kegiatan kelompoknya.

Berdasarkan uraian di atas maka peneliti memilih judul "Pengembangan Perangkat Pembelajaran Kimia Model Kooperatif dengan Pendekatan Inkuiri untuk Meningkatkan Keterampilan Berpikir Kritis Siswa SMA".

Berdasarkan latar belakang di atas maka rumusan masalah disusun sebagai berikut:

1. Bagaimanakah kelayakan perangkat pembelajaran model kooperatif dengan pendekatan inkuiri yang dikembangkan?

2. Bagaimanakah kepraktisan perangkat pembelajaran model kooperatif dengan pendekatan inkuiri yang dikembangkan?

3. Bagaimanakah efektivitas pembelajaran dengan menggunakan perangkat pembelajaran model kooperatif dengan pendekatan inkuiri yang dikembangkan?

4. Bagaimanakah keterampilan berpikir kritis siswa setelah diterapkan pembelajaran model kooperatif dengan pendekatan inkuiri?

\section{METODE PENELITIAN}

Penelitian ini adalah penelitian pengembangan (development research) yang dilaksanakan di SMA N 5 Tuban pada bulan maret 2014. Subjek penelitian ini adalah perangkat pembelajaran model kooperatif tipe STAD dengan pendekatan inkuiri yang meliputi: Silabus, Rencana Pelaksanaan Pembelajaran (RPP), Buku Ajar Siswa (BAS), Tes Keterampilan Berpikir Kritis (TKBK), dan Tes Hasil Belajar Siswa (THB). Sasaran penelitian ini adalah siswa SMA N 5 Tuban Kelas XI IPA sebanyak 33 siswa.

Penelitian ini dilaksanakan melalui tiga tahap, yaitu pengembangan perangkat dengan model Thiagarajan yaitu model 4-D (Four-D Models), validasi perangkat, dan ujicoba lapangan melalui rancangan one group pretest-posttest design, dengan pola sebagai berikut:

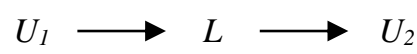

Keterangan:

$$
U_{l}=\text { Preetest }
$$

$$
\begin{aligned}
& L=\text { Perlakuan atau model pembelajaran } \\
& U_{2}=\text { Postest }
\end{aligned}
$$

Kegiatan diawali dengan pemberian tes awal (pretes) $U_{I}$ kepada siswa, kemudian dilakukan proses pembelajaran dengan pembelajaran model kooperatif tipe STAD dengan pendekatan inkuiri $L$, dan setelah pembelajaran dilakukan tes akhir (postes) $U_{2}$ untuk mengetahui keterampilan berpikir kritis dan ketuntasan hasil belajar. Setelah pos test siswa diminta mengisi angket respon terhadap perangkat model pembelajaran yang digunakan.

Teknik yang digunakan untuk mengumpulkan data adalah observasi/pengamatan untuk mengetahui keterlaksanaan RPP, aktivitas siswa dan kendalakendala selama pembelajaran berlangsung, teknik tes digunakan untuk mengukur keterampilan berpikir kritis dan hasil belajar siswa, dan teknik angket digunakan untuk mengumpulkan informasi tentang data respon siswa terhadap kegiatan pembelajaran.

Teknik analisis data secara deskriptif kuantitatif antara lain analisis kelayakan, kepraktisan, dan keefektifan perangkat pembelajaran, analisis tes keterampilan berpikir kritis, dan analisis tes hasil belajar. Melalui analisis data nantinya akan dapat diketahui perangkat pembelajaran yang dikembangkan apa layak, praktis, dan efektif untuk meningkatkan keterampilan berpikir kritis siswa.

\section{HASIL PENELITIAN DAN DISKUSI}

Pada awal pengembangan perangkat pembelajaran kimia model pembelajaran kooperatif tipe STAD dengan pendekatan inkuiri untuk meningkatkan keterampilan berpikir kritis dilakukan validasi oleh pakar terhadap perangkat pembelajaran yang meliputi silabus, RPP, Buku Ajar Siswa, LKS, dan Lembar Penilaian.

Hasil validasi silabus mendapat nilai 3,9 dengan kategori baik dan reliabilitas rata-rata 98. Aspek yang dinilai pada validasi RPP, yaitu tujuan pembelajaran, kegiatan pembelajaran, waktu, metode sajian, dan bahasa. Skor rata-rata dari aspek-aspek RPP yang dinilai adalah 3,3 dengan realibilitas 86 . Hasil validasi menunjukkan RPP yang disusun berkategori baik dengan sedikit revisi. Revisi dilakukan berdasarkan saran-saran dari validator. Validasi BAS meliputi komponen kelayakan isi dengan skor rata-rata 3,6, bahasa dengan skor rata-rata 3,2, dan penyajian dengan skor rata-rata 3,3. Skor rata-rata seluruh komponen BAS adalah 3.4 dengan kategori baik dan realibilitas yang dipeoleh 92. Hasil validasi Lembar Kegiatan Siswa yang meliputi penilaian pada aspek petunjuk, kelayakan isi, prosedur, dan pertanyaan memperoleh rata-rata skor 3,2 dengan realibilitas 93. Hal ini 
menunjukkan LKS yang disusun dalam kategori baik dengan sedikit revisi berdasarkan saran dari validator.

Lembar Penilaian (LP) meliputi Tes Keterampilan Berpikir Kritis (TKBK), Tes Hasil Belajar (THB), dan Lembar Penilaian Afektif. Hasil validasi Lembar Penilaian TKBK yang meliputi penilaian pada validitas isi serta bahasa dan penulisan soal memperoleh nilai 3,1 dengan kategori baik, sedangkan realibilitas rata-rata yang diperoleh adalah 93. Hasil validasi Lembar Penilaian THB yang meliputi validitas isi serta bahasa dan penulisan soal memperoleh nilai 3,1 dengan kategori baik, sedangkan realibilitas rata-rata 94 . Revisi pada TKBK dilakukan pada butir soal nomer 5, 8, 9, dan 21. Revisi dilakukan dengan memperbaiki pada struktur kalimat dan option jawaban. Revisi pada THB dilakukan pada butir soal nomer 2, 3, 5, dan 6. Revisi dilakukan dengan memperbaiki option pertanyaan dan jawaban. Lembar penilaian afektif dinyatakan baik dan dapat digunakan dengan revisi kecil.

Tingkat kesulitan rata-rata untuk BAS adalah 21\% dan LKS adalah $21 \%$, sehingga kedua perangkat tersebut termasuk dalam kategori tingkat kesulitan rendah dan materi mudah difahami oleh siswa. Tingkat keterbacaan BAS adalah 77\% dan LKS adalah $78 \%$. Hal ini menunjukkan bahwa kedua perangkat mempunyai tingkat keterbacaan tinggi dan mudah difahami oleh siswa.

Pengamatan terhadap keterlaksanaan RPP selama pertemuan 1, 2, dan 3 meliputi pendahuluan, kegiatan inti, penutup, suasana kelas, dan pengelolaan waktu. Keterlaksanaan sintak pada pendahuluan mendapat nilai 3,92 yang berarti dapat menciptakan suasana pembelajaran yang efektif, sehingga proses belajar mengajar dapat berlangsung dengan baik.

Tahapan inti terdiri dari menyajikan informasi yang memperoleh nilai 3,92, mengorganisasikan siswa ke dalam kelompok memperoleh nilai 4, dan membimbing siswa bekerja dalam tim mendapatkan nilai 3,67. Tahapan penutup adalah pemberian penghargaan yang memperoleh nilai rata-rata sebesar 4 . Penilaian terhadap suasana kelas yang meliputi antusias siswa dan guru mendapat nilai 4 . Pada pengelolaan waktu mendapat nilai rata-rata 3,42. Pengelolaan waktu mendapat nilai yang paling rendah dibandingkan tahapan yang lain. Hal ini disebabkan pada saat pertemuan pertama, pengelolaan waktu belum dapat berlangsung dengan baik karena siswa belum terbiasa melaksanakan kegiatan pembelajaran inkuiri dan menggunakan alat-alat di laboratorium sehingga dibutuhkan waktu yang lebih lama.

Berdasarkan pembahasan di atas menunjukkan bahwa keterlaksanaan penerapan perangkat pembelajaran model kooperatif tipe STAD dengan pendekatan ikuiri dapat terlaksana dengan baik dengan nilai rata-rata dari semua tahap adalah 3,8 dengan reliabilitas 98,7.

Efektivitas penerapan perangkat pembelajaran model kooperatif dengan pendekatan inkuiri dapat diketahui dengan mengamati hasil tes kemampuan berpikir kritis, tes hasil belajar, dan respon siswa terhadap pembelajaran. Hasil analisis $N$-Gain rata-rata menunjukkan bahwa nilai $N$-Gain rata-rata untuk indikator I (merumuskan masalah 0,71), indikator II (membuat argumen 0,78), indikator III (menunjukkan perbedaan 0,80 ), indikator IV (menyusun hipotesis 0,68 ), indikator $\mathrm{V}$ (menyusun rancangan penyelesaian masalah 0,73), indikator VI (menganalisis data 0,69), indikator VII (menarik kesimpulan 0,76), dan indikator VIII (memilih kemungkinan yang akan dilaksanakan 0,67). Hal ini menunjukkan terjadi peningkatan keterampilan berpikir kritis dengan kategori yang berbeda. Peningkatan keterampilan berpikir kritis dengan kategori tinggi terjadi pada indikator merumuskan masalah, membuat argumen, menunjukkan perbedaan, menyusun rancangan penyelesaian masalah, dan menarik kesimpulan. Indikator berpikir kritis dengan kategori sedang terjadi pada indikator menyusun hipotesis, menyusun rancangan penyelesaian masalah, menganalisis data, dan memilih kemungkinan yang akan dilaksanakan.

Peningkatan yang tinggi pada indikator I, II, III, $\mathrm{V}$, dan VII berhubungan dengan pembelajaran model kooperatif tipe STAD dengan pendekatan inkuiri yang diterapkan. Peningkatan yang tinggi pada indikator I ini dikarenakan siswa dilatih membuat pertanyaanpertanyaan dari permasalahan yang terjadi dalam kehidupan sehari-hari. Berdasarkan pertanyaan tersebut siswa dilatih mengidentifikasi variabel-variabel dalam permasalahan yang dinyatakan dengan pertanyaan. Selanjutnya siswa dibimbing untuk mengaitkan antar variabel menjadi sebuah rumusan masalah yang menuntun siswa untuk menemukan jawaban atas permasalahan yang dihadapi. Oleh karena itu siswa mendapatkan pengalaman belajar baru yang sebelumnya belum pernah mereka temui.

Peningkatan yang tinggi pada indikator II dan III dikarenakan pada saat melaksanakan kegiatan inkuiri yang dilakukan secara koopertif siswa melakukan interaksi dengan teman sekelompoknya dengan berdiskusi, bertukar ide dan pendapat dalam memecahkan permasalahan. Melalui pembelajaran kooperatif siswa akan lebih mudah menemukan dan memahami konsep yang sulit apabila mereka dapat saling mendiskusikan masalah-masalah tersebut dengan temannya (Slavin, 2006). Siswa juga melakukan presentasi secara kelompok untuk menyampaikan hasil analisis data yang memungkinkan adanya pertanyaan dan argumen diantara kelompok. Pada saat 
pembelajaran inkuiri siswa berdiskusi secara mendalam tentang penelitian meliputi masalah, data, peranan tehnologi, menginterpretasikan data, dan kesimpulan yang telah diperoleh oleh para ilmuwan (National Reseach Council: 2001). Adanya kegiatan diskusi dalam kelompok, tanya jawab antar kelompok, dan tanya jawab antara siswa dan guru dapat meningkatkan kemampuan berargumentasi siswa, disamping itu siswa juga melakukan diskusi tentang perbedaan-perbedaan.

Peningkatan yang tinggi juga terjadi pada indikator V dan VII. Peningkatan yang tinggi pada indikator $\mathrm{V}$ yaitu menyusun rancangan penyelesaian masalah dikarenakan siswa dilatih untuk merencanakan sendiri langkah-langkah yang akan dilaksanakan dalam melakukan penyelidikan, sehingga siswa mempunyai pengalaman untuk menyusun rancangan penyelesaian masalah jika dihadapkan pada suatu masalah. Peningkatan pada indikator VII dikarenakan selama pembelajaran siswa dilatih untuk membuat kesimpulan yang diperoleh berdasarkan hasil imterpretasi data. Pada pembelajaran inkuiri terjadi rangkaian kegiatan belajar yang melibatkan secara maksimal seluruh kemampuan siswa untuk mencari dan menyelidiki secara sistematis, kritis, logis, dan analitis, sehingga mereka dapat merumuskan sendiri penemuannya dengan penuh percaya diri (Gulo, 2002). Siswa mempunyai pengalaman baru dalam menganalisis data dan membuat kesimpulan yang sebelumnya belum mereka dapatkan.

Terjadi peningkatan dengan kategori sedang pada indikator IV, VI, dan VIII, yaitu indikator menyusun hipotesis, menganalisis data dan memilih kemungkinan yang akan dilaksanakan. Hal ini disebabkan belum optimalnya siswa dalam melakukan hipotesis dan dibutuhkannya pengetahuan yang lebih luas untuk menganalisis data dan memilih kemungkinankemungkinan yang akan dilaksanakan.

Peningkatan keterampilan berpikir kritis siswa secara klasikal meningkat dengan nilai rata-rata $\mathrm{N}$-Gain 0,75 dengan kategori tinggi. Peningkatan keterampilan berpikir kritis yang tinggi juga didukung oleh keterlaksanaan RPP pembelajaran model kooperatif tipe STAD dengan pendekatan inkuiri dengan kategori baik, disamping itu juga didukung oleh aktivitas siswa yang tinggi dalam pelaksanaan pembelajaran. Sebanyak $78 \%$ siswa dapat mencapai KKM $(\mathrm{KKM} \geq 75)$ dan sisanya $22 \%$ berada di bawah KKM.

Hasil analisis pre tes dan pos tes menunjukkan bahwa hasil belajar produk siswa mengalami peningkatan. Hasil pre tes menunjukkan tidak ada siswa yang tuntas hasil belajarnya, sedangkan pada post tes sebanyak $91 \%$ siswa mengalami ketuntasan dengan $\mathrm{KKM} \geq 75$. Hasil yang diperoleh menunjukkan proses pembelajaran yang dilakukan menggunakan pembelajaran model koopertif tipe STAD dengan pendekatan inkuiri membuat siswa memahami konsep yang dipelajari. Data hasil tes juga menunjukkan bahwa 9\% siswa tidak tuntas secara individual. Hasil ini mengindikasikan bahwa tidak semua siswa terlibat secara aktif membangun pengetahuannya, sehingga kurang memahami konsep dengan baik.

Hasil belajar afektif siswa terutama keterampilan sosial menunjukkan perkembangan yang konsisten. Hal ini disebabkan pada saat pembelajaran siswa secara aktif membangun pengetahuannya lewat interaksinya dengan orang lain. Hal ini ditandai dengan aktifnya siswa dalam bekerja sama menyelesaikan masalah secara bersama-sama, menjadi pendengar ketika mendapatkan masukan atau informasi-informasi yang berguna dan mengungkapkan ide atau pendapat dalam menanggapi suatu masalah berdasarkan pengetahuan atau informasi yang telah diperoleh.

Hasil analisis respon siswa menunjukkan bahwa sebagian besar (95\%) siswa memberikan respon positif terhadap perangkat pembelajaran model kooperatif tipe STAD dengan pendekatan inkuiri yang telah dilaksanakan, walaupun $96 \%$ siswa menyatakan pembelajaran seperti ini hal yang baru bagi mereka.

Kendala utama yang ditemui selama pembelajaran adalah proses pembelajaran belum dapat selesai sesuai waktu yang dialokasikan. Hal ini disebabkan siswa belum terbiasa dengan pembelajaran model kooperatif dengan pendekatan inkuiri, siswa belum terbiasa bekerja menggunakan alat-alat laboratorium, pada saat pembelajaran siswa masih ramai, siswa masih sulit untuk bertanya dan mengeluarkan pendapat.

\section{KESIMPULAN}

\section{A. Simpulan}

Berdasarkan hasil analisis dan pembahasan, maka dapat disimpulkan sebagai berikut:

1. Pengembangan perangkat pembelajaran kimia model kooperatif dengan pendekatan inkuiri untuk meningkan keterampilan berpikir kritis siswa SMA yang berupa silabus, RPP, BAS, LKS, dan lembar penilaian mencapai kriteria valid dengan kategori baik.

2. Perangkat pembelajaran kimia model kooperatif dengan pendekatan inkuiri untuk meningkan keterampilan berpikir kritis siswa SMA mencapai kriteria praktis dengan persentase rata-rata keterlaksanaan RPP pada pertemuan pertama, kedua, dan ketiga mencapai nilai 3,8 dengan kategori baik.

3. Perangkat pembelajaran kimia model kooperatif dengan pendekatan inkuiri untuk meningkan keterampilan berpikir kritis siswa SMA mencapai kriteria efektif, dengan adanya peningkatan nilai pretes dan postes dengan nilai $N$-Gain 0,72 dengan kategori tinggi. Hasil belajar siswa mencapai ketuntasan secara klasikal sebesar $91 \%$. 
4. Penerapan perangkat pembelajaran model kooperatif dengan pendekatan inkuiri dapat meningkatkan keterampilan berpikir kritis siswa, ditandai dengan hasil $N$-Gain indikator keterampilan berpikir kritis merumuskan masalah 0,71 (kategori tinggi), membuat argumen 0,75 (kategori tinggi), menunjukkan perbedaan 0,80 (kategori tinggi), menyusun hipotesis 0,68 (kategori sedang), menyususn rancangan penyelesaian masalah 0,73 (kategori tinggi), menganalisis data 0,69 (kategori sedang). Menarik kesimpulan 0.76 (kategori tinggi), dan memilih kemungkinan yang akan dilaksanakan 0,67 (kategori sedang).

\section{B. Saran}

Berdasarkan hasil penelitian yang telah dilakukan, peneliti dapat memberi saran:

1. Pembelajaran model kooperatif dengan pendekatan inkuiri memerlukan waktu yang lebih lama, sehingga dalam merencanakan pembelajaran model kooperatif dengan pendekatan inkuiri perlu mengalokasikan waktu lebih banyak.

2. Guru selalu mengamati perilaku siawa yang tidak relevan pada saat melakukan aktivitas diskusi dan kerjasama dalam kelompok, serta segera memberi peringatan jika terjadi perilaku tidak relevan.

3. Memberi latihan pada siswa di luar jam pelajaran, jika siswa belum terlatih dengan kegiatan inkuiri, misalnya penggunaan alat dan menggambar grafik yang benar.

4. Pembelajaran model kooperatif dengan pendekatan inkuiri merupakan salah satu model pembelajaran yang dapat dijadikan alternatif untuk meningkatkan keterampilan berpikir kritis siswa, sehingga perangkat ini perlu dikembangkan dan diimplementasikan pada topik lain yang sesuai.

\section{REFERENSI}

Anderson, L. W., Krathwohl, D. R., Airasian, and Peer, W. (2001). A Taxonomy For Learning,Teaching, and Assesing. United State: Longman.

Arikunto, S. (2005). Dasar-dasar Evaluasi Pendidikan. Jakarta: Bumi Aksara.

Arends. R. I. (1997). Classroom Instruction and Management. New York: McGraw-Hill, inc.

Arends. R. I.(2009). Learning To Teach, (Ninth Edition). New York: McGraw-Hill, inc.

Arifin, Z. (2010). Evaluasi Pembelajaran Prinsip, Teknik dan Prosedur. Bandung: Remaja Rosdakarya.

Badan Standart Nasional Pendidikan. (2006). Standart Isi untuk Satuan Pendidikan Dasar dan Menengah. Jakarta: BNSP.
Callahan, J. F. Clark, L. H. And Kellough, R. D. (1992). Teaching in Middle and secondary Schools. New York: Macmillan Publishing Company.

Dahar, R. W. (2006). Teori-teori Belajar dan Pembelajaran. Jakarta: Erlangga.

Depdiknas. (2006). Model Silabus Dan Rencana Pelaksanaan Pembelajaran. Jakarta: BNSP.

Depdiknas. (2007a). Kajian Kebijakan Kurikulum Mata Pelajaran IPA. Jakarta: Puskur Depdiknas.

Depdiknas. (2007b). Peraturan Menteri Pendidikan Nasional Republik Indonesia Nomor 41 Tahun 2007. Tentang Standar Proses Untuk Satuan Pendidikan Dasar dan Menengah. Jakarta: BNSP.

Depdiknas. (2008). Kriteria dan Indikator Keberhasilan Pembelajaran. Jakarta: Direktorat Tenaga Kependidikan.

Eggen, P. D., and Kauchak, D. P. (1996). Strategies for Teachers Teaching Content and Thinking Skill Third Edition. Boston: Allyn and Bacon.

Ennis, R. H. (1996). Critical Thinking. New Jersey: Prentice Hall.

Facione, P. A. (2011). Critical Thinking: What It and Why It Counts. CA: The California Academic Press.

Fischer, A. (2009). Berpikir Kritis Sebuah Pengantar. Jakarta: Erlangga.

Gronlund, N. E. (1982). Constructing Achievement Tests. United State of Amerika: Englewood Cliffs.

Hake, R. R. (1999). "Analyzing Change/Gain Scores". Woodlan Hills, Indiana University Journal. CA. 91367 USA

Kardi, S. (2002). Mengembangkan Tes Hasil Belajar. Diktat Matakuliah PBP. Surabaya: Pendidikan Sains PPs: Universitas Negeri Surabaya.

Klimoviena, G., Urbaniene, J., and Barzdziukiene, R. (2006). "Developing Critical Thinking Through Cooperative learning". ISSN 16482824 KALBU STDIJOS. 9NR

Lai, E. L. 2011. Critical Thinking: A Literature Review Research Report. Pearson: http://www.pearsonassesments.com/research. Diakses 22 juni 2012

National Research Council. (1999). National Science Education Standarts. Washington DC: National Academy Press.

National Research Council. (2001). Inquiry and The National Science Education Standarts. Washington DC: National Academy Press.

Nur, M. (2011). Model Pembelajaran Kooperatif. Surabaya: PSMS Unesa.

Prabowo. (2011). Metodologi Penelitian. Surabaya: Unesa University Press. 
Purwanto, M. N. (2009). Prinsip-prinsip dan Teknnik Evaluasi Pengajaran. Bandung: PT Remaja Rosdakarya.

Ratumanan, T. G. R., dan Laurens, T. (2003). Evaluasi Hasil Belajar. Surabaya: Unesa University Press.

Rindell, A. J. A. (1999). “Applying Inquiry-Based and Cooperative Group Learning Strategis Promoted Critical Thinking". Journal of Collage Science Teaching (JCTS). Vol. 28, No. 3, pp. 203-207.

Schafersman, S. D. (2006). An Intruduction of Critical Thinking. www.freeinquiri.com/critical Thinking.html. Diakses 20 februari 2013.
Slavin, R. E. (2005). Cooperative Learning Teori, Riset dan Praktik. Bandung: Nusa Media.

Slavin, R. E. (2006). Educational Psycology Theory and Practice Eigh Edition. USA: Prentice Hall.

Thiagarajan, S., Semmel, S., and Semmel. I. M. (1974). Instructional Development for Training Teachers of Exceptional Children. Indiana: Indiana University.

Trisdiono. (2013). Strategi Pembelajaran Abad 21. http://www.lpmpjogja.org/index.php?option $=c$ om_content $\&$ view $=$ article $\& i d=26:$ strategi pembelajaran-abad-21\&catid=13: harlitrisdiono-mm\&Itemid=22. Diakses 12 juli 2013.

Woolfolk, A. (2009). Educational Psycology. Yogyakarta: Pustaka Pelajar. 